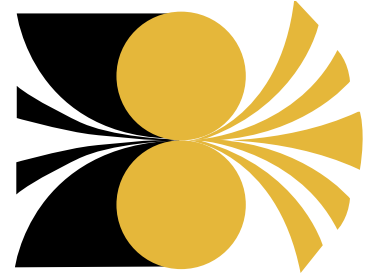

GOLD 2003

NEW INDUSTRIAL USES FOR GOLD
Gold 2003

28 September - 1 October 2003
Co-organisers:

World Gold Council

Canadian Institute of Mining, Metallurgy \& Petroleum

Sponsor:

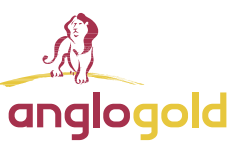

\section{First Announcement and Call for Papers}

\section{Patrons}

Prof Geoffrey Bond, University of Salford, UK

Dr Masatake Haruta, Research Institute for Green

Technology, AIST, Japan

Prof Hubert Schmidbaur, Technical University of

Munich, Germany

The field of gold science and technology is currently undergoing an exciting period of discovery. Many scientists and technologists in academia and industry have expressed the need for a forum where they can come together to learn of and discuss the latest advances, with the overall objective of encouraging important new industrial applications for gold.

World Gold Council and The Canadian Institute of Mining, Metallurgy and Petroleum (CIM) are pleased, therefore, to announce their joint organisation of the international conference on the science, technology and industrial applications of gold, which will be held in Vancouver during 28 September - 1 October 2003.
This conference follows the successful and stimulating 'Catalytic Gold' conference held in Cape Town, South Africa in April 2001 and builds on the more general meeting on 'Progress in the Science and Technology of Gold' which took place in Hanau, Germany in June 1996. The 'Gold 2003' conference will cover all aspects of the science, technology and applications of gold under four principal themes:

- Catalysis

- Chemistry

- Materials

- Nanotechnology

Each major area will be introduced by an invited senior keynote speaker who will review the major scientific issues in the field. The programme for each of these themes will be organised by separate technical committees. The programme will be especially designed to ensure that industrial participants can assess the potential application of recent advances in gold research and open discussion will be encouraged. For those new to the field, orientation workshop sessions will take place on Sunday, 28 September. There will also be an interesting and attractive spouse/partners programme.

\title{
Scope
}

The Conference welcome technical papers or posters on, but not limited to, the following topics:

\section{Catalysis}

- Alloy catalysts

- Applications - fuel cells, pollution control, chemical processing, sensors

- Catalyst preparation and characterisation

- Chemistry on gold surfaces

- Electrocatalysis

- Gas and liquid phase heterogeneous systems

- Gold-support interaction

- Homogeneous systems

\section{Materials}

- Alloys and metallurgy

- Coating technology

- Composites and novel materials

- Decorative technologies

- Dental materials and applications

- Electroless and immersion gold deposition

- Electronic materials applications

- Electroplating and electroforming

\section{Nanotechnology}

- Applications - decorative, electronic, medical

- Colloid technology

- Cluster science

- Nanoparticles and wires preparation \& characterisation

- Photophysical properties

- Self assembly systems 


\section{Committee Chairmen Organising Committee}

Dr Christopher W Corti, World Gold Council, UK

Mr Serge Major, CIM, Canada (Vice)

Technical Programme Co-ordinator

Dr David Thompson, Consultant to WGC, UK

\section{Catalysis Committee}

Prof Bernard E Nieuwenhuys, Leiden University,

The Netherlands

Dr Larry Ito, The Dow Chemical Company, USA

\section{Chemistry Committee}

Prof Antonio Laguna, University of Zaragoza, Spain

Dr Barry Murrer, Johnson Matthey plc, U.K.

\section{Materials Committee}

Dr Richard Holliday, World Gold Council, London, UK

Prof Alan Russell, lowa State University, USA

\section{Nanotechnology Committee}

Prof Mike Cortie, University of Technology Sydney, Australia

Dr Bruce Cornell, AMBI Ltd, Australia

A full list of committee members will be found on the conference website.

\section{Venue}

Vancouver is the venue for the Gold 2003 conference. The Conference hotel is the Westin Bayshore Resort and Marina, Vancouver, nestled on the shores of Coal Harbour and overlooking the third largest city park in North America the 1,000 acre Stanley Park - with the breathtaking Coastal Mountains beyond. This excellent location provides direct access to Vancouver's most popular business, shopping and entertainment districts. This award winning hotel and new Conference Centre offers superb facilities for an international conference and provides for excellent accommodation.

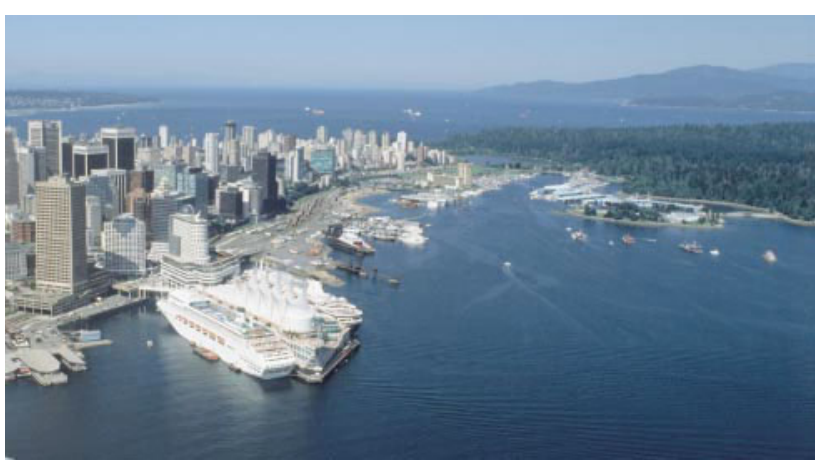

\section{Key dates}

Deadline for extended abstracts

Notice for acceptance of abstracts

Camera-ready papers from authors

Jan 152003

Mar 312003

August 12003

\section{Website}

Full information on the conference can be found on the conference website at www.gold2003.org

\section{Proceedings}

Proceedings will be published as a separate book.

\section{Students}

Special student rates for conference attendance will be announced on the website in due course.

\section{Call for papers}

Extended abstracts for proposed papers or posters should be submitted via the conference website at www.gold2003.org

Extended abstracts should be approximately 2 x A4 pages (single spacing) in length (about 1000 words).

Questions regarding the conference technical programme should be addressed to:

\section{Technical Programme Co-ordinator}

Gold 2003

International Technology

World Gold Council

45 Pall Mall, London

\section{SW1Y 5JG}

UK.

Fax: $\quad+442078396561$

Email: gold2003@gold.org

Please send me full programme and registration information I am interested in the following session(s) - tick all those that apply

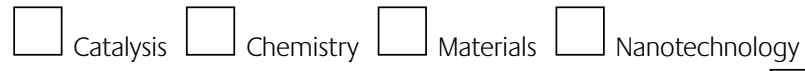

I intend to submit an abstract for oral presentation

I intend to submit an abstract for poster presentation

I intend to participate as a delegate only

My spouse/partner is likely to attend with me

Title _ First name

Last name

Position

Organisation

Address

City

Postal/zip code Country Tel

Fax Email

\section{Send to:}

Gold 2003 Conference Secretariat

Canadian Institute of Mining Metallurgy and Petroleum

3400 de Maisonneuve Blvd West Suite 1210

Montreal

Quebec

Canada

H3Z 3B8

Fax: +1 5149395587

Email: smajor@cim.org 